\title{
CROATIAN AND GERMAN ACCOUNTING - A GUIDING OVERVIEW OF REGULATIONS AGAINST THE BACKGROUND OF THE ACCOUNTING DIRECTIVE 2013/34/EU
}

\author{
Ivana Mamić Sačer* \\ Gunther Meeh-Bunse ** \\ Katja Luer ${ }^{* * *}$
}

\begin{abstract}
The Accounting Directive 2013/34/EU has impacted all the EU Member States due to their obligation to transpose it into the national legal acts. The paper deals with the Croatian and German regulations against the Accounting Directive. Since the Directive offers several alternatives for which national regulators should decide what to include in the legal framework, there are certain differences among the EU Member states. The goal of the paper is to analyze the case of Croatian and German accounting in the light of regulations and standards. The selected countries are important strategic and trading partners and the number of subsidiaries in Croatia formed by German entities increases. The methodology includes the analysis of accounting legal framework in the observed countries in the light of the Accounting Directive implementation, the role of Companies act and the financial reporting standards in prescribing accounting principles and the interrelation between financial and tax accounting. Although both countries have implemented the Directive, our research results indicate that there is a difference between the accounting systems. German accounting principles are defined through the German Companies Act whereas the Croatian Accounting Act represents the top act in charge of accounting in Croatia supplemented with the CFRS and IFRS. As a consequence, the difference is also found in the interdependence between financial and tax accounting. However, there
\end{abstract}

Full professor at Faculty of Economics and Business University of Zagreb; imamic@efzg.hr.

** Full professor, Hochschule Osnabrück, Lingen Campus; G.Meeh-Bunse@hs-osnabrueck.de.

*** Research Assistant, Hochschule Osnabrück, Lingen Campus; K.Luer@hs-osnabrueck.de. 
are some similarities indicated, as the commercial balance sheet should be adjusted for the purpose of taxation in both countries.

KEYWORDS: accounting act, accounting directive, companies act, Croatia, Germany

\section{INTRODUCTION}

Traditionally the economic relations between Croatia and Germany have been very close. Currently Germany is Croatia's largest trading partner. In addition to major German investments, ${ }^{1}$ numerous small and medium-sized German entities have set up subsidiaries in Croatia. ' $T$ 'The main investing countries are the Netherlands (20.7\% of total FDI between 1993 and 2017), Austria (12.3\%), Italy (10.4\%) and Germany (9.4\%). " 3 Other than that, the proportion of goods export to Germany is around $13 \%$ whereas the export of services from Croatia to Germany is $20 \%$ of total export. ${ }^{4}$ Directly supporting this economic activity is the knowledge of mutual accounting principles: Mutual understanding of the business partners' financial statements are a significant basis for trust and reliability in any business relationship. ${ }^{5}$ Supporting e.g. a beneficial financial statement analysis or consolidating single accounts ${ }^{6}$, the European Union connects Croatian and German Accounting with it's for both countries legally binding regulations. ${ }^{7}$ Drawing on the example of a starting business relationship: The reliability with re-

\footnotetext{
1 See for example, [https://www.telekom.com/en/company/worldwide/profile/deutsche-telekom-in-croatia-355850] accessed on 29.10.2018 or [https://www.siemens.com/global/en/home/ company/about/history/countries/croatia.html] accessed on 29/10/2018.

2 [https://www.auswaertiges-amt.de/en/aussenpolitik/laenderinformationen/kroatien-node/ croatia/228804] accessed on 29/10/2018.

3 [https://en.portal.santandertrade.com/establish-overseas/croatia/investing] accessed on 20/5/2019.

4 https://www.hgk.hr/documents/analizautjecaj-njemacke-na-kretanje-hrvatskog-gospodarstva3195c9cdb8bd4dc6.pdf] accessed on 20/5/2019

5 Approximately 3.2 million entities in Germany alone have the duty to keep books, derived from [https://www-genesis.destatis.de/genesis/online/data;sid=4716881764427D759DB81CA028DB82E5.GO_1_3] accessed on 20/5/2019 as well as Bundesministerium der Finanzen, Datensammlung zur Steuerpolitik, Berlin 2018, p. 63.

6 See also IFRS 10 (2018) International Financial Reporting Standards, [http://www.ifrsportal.com/Publikationen/IFRS_Texte.htm] accessed on 03/06/2019.

7 Regulations and Decisions become binding automatically within the European Union on the date they enter into force, whereas directives must be incorporated by the European Union member states into their national law, see Treaty on the Functioning of the European Union [Official Journal of the European Union, C 326/47, 2010], Art. 288 (2) and Art. 288 (3).
} 
gard to solvency and future supply may be crucial factors. Financial statements can therefore be described as a meaningful business card for financial strength. '

The following elaboration is intended as a guiding overview of regulations on accounting including a national, a supranational and an international level to point out differences and common ground between the legal frameworks of accounting in Croatia and Germany.

\section{GERMAN FINANCIAL REPORTING: STANDARDS AND REGULATIONS}

Topics, as well as the extent of German financial accounting, are defined by several legal accounting frameworks. From a German perspective, the German Commercial $\mathrm{Code}^{8}$ codifies generally accepted accounting principles on a national level. Furthermore, the European Union legislated the EU Accounting Directive $^{9}$, which is legally binding for German entities (as well as for Croatian and all other European Union member state entities). ${ }^{10}$ Closing this holistic view the International Reporting Standards (IFRS) set generally accepted accounting principles on an international level. ${ }^{11}$ The IFRS are published by the International Accounting Standards Board (IASB) and are most times adopted by the European Union for capital market-orientated entities within its member states. The latter two are implemented respectively embedded in the German Commercial Code.

\footnotetext{
8 Rittler, T.: Handelsgesetzbuch (HGB) - German Commercial Code, Gründau, 2017.

9 See European Union: Directive 2013/34/EU, [https://eur-lex.europa.eu/legal-content/EN/ TXT/?uri=CELEX:32013L0034] accessed on 23/11/2018. For more information please see European Commission: Accounting rules - Directive 2013/34/EU, [https://ec.europa.eu/info/law/ accounting-rules-directive-2013-34-eu_en] accessed on 23/11/2018.

10 Treaty on the Functioning of the European Union [Official Journal of the European Union, C 326/47, 2010], Art. 51 (1) and Art. 288 (3) in conjunction with Directive 2013/34/EU [Official Journal of the European Union, L 182/19, 2013], Art. 55.

11 See for more information [https://www.ifrs.org/about-us/] accessed on 23/11/2018.
} 


\section{Figure 1: Topics and extend of accounting ${ }^{12}$}

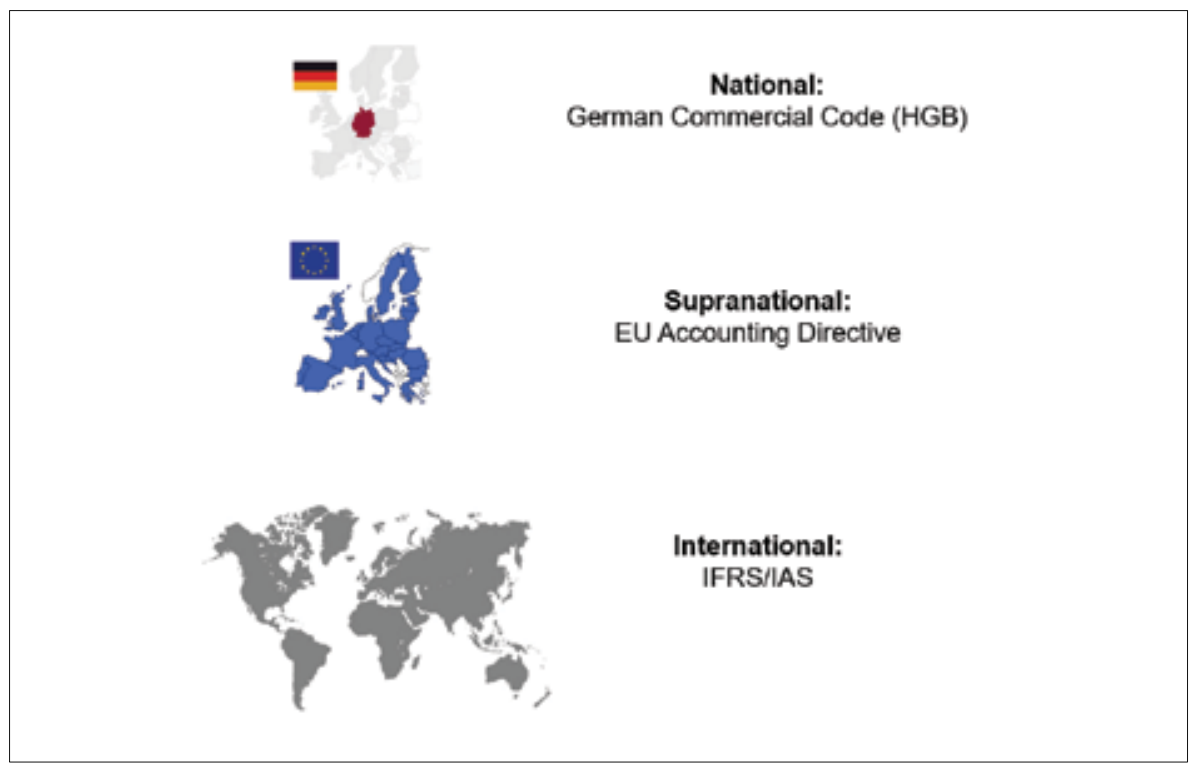

Concerning the (German) national level the most distinguished and legally binding regulation is the German Commercial Code (GCC: "Handelsgesetzbuch"), in Germany commonly abbreviated as HGB..$^{13}$ Attention should be paid to the fact that only a small part of the German Commercial Code is focusing on accounting ( $3^{\text {rd }}$ book). ${ }^{14}$ In the further course of this paper, we refer to this $3^{\text {rd }}$ book.

Although the overall objective is to ensure an equal treatment for all corporate firms (corporations, limited and general partnerships as well as sole propri-

12 For corresponding regulations see Rittler, T.: Handelsgesetzbuch (HGB) - German Commercial Code, Gründau, 2017 as well as European Union: Directive 2013/34/EU, [https://eur-lex.europa.eu/legal-content/EN/TXT/?uri=CELEX:32013L0034] accessed on 12/03/2019 and [http://eifrs.ifrs.org/eifrs/PDFArchive?categoryId=3\&sidebarCategoryId=3] accessed on 12/03/2019. For the country-images see [https://www.istockphoto.com/ch/vektor/flagge-von-deutschland-und-bezeichnung-auf-der-weltkarte-gm466876338-60722844] accessed on 20/05/2019, [https://de.depositphotos.com/51647321/stock-illustration-europe-map-with-the-european.html] accessed on 20/05/2019 as well as [https://de.freepik.com/ vektoren-kostenlos/grau-weltkarte_893780.htm] accessed on 20/05/2019.

13 The German Commercial Code is called "Handelsgesetzbuch (HGB)" in its origin.

14 The $1^{\text {st }}$ book is focused on specifying the merchant class, the $2^{\text {nd }}$ book on characterizing commercial and silent partnerships, the $4^{\text {th }}$ book deals with the treatment of commercial transactions and the $5^{\text {th }}$ book is related to maritime trade. See for more detailed structure, topics and content Rittler, T.: Handelsgesetzbuch (HGB) - German Commercial Code, Gründau, 2017. 
etorships), there are supplementary regulations for entities depending on their size $^{15}$, group structure, business activity and their capital market activity ${ }^{16} \cdot{ }^{17}$

In general, the German Commercial Code pursues three objectives:

- Full documentation (e.g. business transactions or other facts the entity deals with) ${ }^{18}$

- Information to give account to different stakeholders ${ }^{19}$ e.g. lenders as well as suppliers, customers and investors

- Determination of payments ${ }^{20}$ (e.g. taxes on income (authoritativeness of German Commercial Code) ${ }^{21}$ or dividends (e.g. according to German Stock Corporations $\left.\mathrm{Act}^{22}\right){ }^{23}$

These three objectives serve an overall attitude: The protection of lenders and other creditors. ${ }^{24}$ This attitude is not expressly defined, but achieved by several

15 Regarding this characteristic three main criteria are applied, namely the revenue, the balance sheet total and the number of employees of the categorized company. German Commercial Code [German Federal Law Gazette, Part I, p. 1102, 2018], § 267 implements in so far Directive 2013/34/EU [Official Journal of the European Union, L 182/19, 2013], Art. 3 and exploits the threshold set (in (2)).

16 See for example German Commercial Code [German Federal Law Gazette, Part I, p. 1102, 2018] in conjunction with Directive 2013/34/EU [Official Journal of the European Union, L 182/19, 2013], Art. 22 (preparation of consolidated financial statements).

17 See also [https://ec.europa.eu/growth/smes/business-friendly-environment/performance-review_de] accessed on 10/01/2019.

18 See for example German Commercial Code [German Federal Law Gazette, Part I, p. 1102, 2018], § 239 and Directive 2013/34/EU [Official Journal of the European Union, L 182/19, 2013], Point 9 of the reasons.

19 See for example German Commercial Code [German Federal Law Gazette, Part I, p. 1102, 2018], § 240 and Directive 2013/34/EU [Official Journal of the European Union, L 182/19, 2013], Point 4 of the reasons.

${ }^{\text {in }}$ conjunction with Coenenberg, A. et al.: Jahresabschluss und Jahresabschlussanalyse, Stuttgart 2018, p. 19.

20 This is a special characteristic of German accounting and not specified in - but also not in contradiction to - Directive 2013/34/EU.

21 See for example German Income Tax Act [German Federal Law Gazette, Part I, p. 357, 2019], § 5 (1).

22 See for example German Stock Corporations Act. [German Federal Law Gazette, Part I, p. 2446, 2017], § 58.

23 See for further information Coenenberg et al.: Jahresabschluss und Jahresabschlussanalyse, Stuttgart 2018, p. 19 et seq.

24 See Coenenberg et al.: Jahresabschluss und Jahresabschlussanalyse, Stuttgart 2018, p. 10 et seq. 
basic principles that find its expressions in the German Commercial Code. ${ }^{25}$ The most important basic principle is the prudence principle. ${ }^{26}$ According to this, entities must not account for their company more valuable than it really is; they need to account "carefully". ${ }^{27}$ In turn, the term "carefully" is defined by two more basic principles: The realization principle specifies that the entity is not allowed to account profit that is only expected but not yet realized ${ }^{28}$, whereas the imparity principle determines an accounting of losses as soon as a foreseeable loss emerged becomes reasonably possible ${ }^{29} \cdot{ }^{30}$

All non-listed companies are obliged to account in accordance with the German Commercial Code, whereas all corporations are entitled to publish single as well as group accounts accounted following the IFRS. ${ }^{31}$

The German Commercial Code determines the components of the financial statements depending on the size of the concerned entities: ${ }^{32}$

25 See for example German Commercial Code [German Federal Law Gazette, Part I, p. 1102, 2018], § 268 (8) in conjunction with Hoffmann, W. et al.: NWB Kommentar Bilanzierung, Herne, 2019, § 268 Point 156.

26 The prudence principle is also a key factor affecting Directive 2013/34/EU, Directive 2013/34/EU [Official Journal of the European Union, L 182/19, 2013], Point 9 of the reasons.

27 See German Commercial Code [German Federal Law Gazette, Part I, p. 1102, 2018], § 252 (1) No. 4 and e. g. Directive 2013/34/EU [Official Journal of the European Union, L 182/19, 2013], Art. 6 (1) lit. c in conjunction with Kahle, Holger; Eichholz, Meik: Allgemeine Bewertungsgrundsätze - Grundsatz der Vorsicht, in Hachmeister et al. (ed.): Bilanzrecht, Köln, 2018, $\S 252$, Point 120 et seqq.

28 See German Commercial Code [German Federal Law Gazette, Part I, p. 1102, 2018], § 252 (1) No. 4, half sentence 1 in conjunction with Directive 2013/34/EU [Official Journal of the European Union, L 182/19, 2013], Art. 6 (1) lit. c Point i).

29 See German Commercial Code [German Federal Law Gazette, Part I, p. 1102, 2018], § 252 (1) No. 4, half sentence 2 in conjunction with Directive 2013/34/EU [Official Journal of the European Union, L 182/19, 2013], Art. 6 (1) lit. c Point ii).

30 See for further information Kahle, Holger; Eichholz, Meik: Allgemeine Bewertungsgrundsätze - Grundsatz der Vorsicht, in Hachmeister et al. (ed.): Bilanzrecht, Köln, 2018, § 252 Point 131 et seqq. as well as Point 147 et seqq.

31 See German Commercial Code [German Federal Law Gazette, Part I, p. 1102, 2018], § 325 (2a) and (3). Please note the facultative size-related disclosure reliefs for small and medium sized companies in $\S \S 326$ et seq. German Commercial Code.

32 In Germany statistics on numbers of companies with a duty to prepare accounts are hardly available. Relevant data is most likely accessed on [https://www.bundesfinanzministerium.de/ Datenportal/start.html] accessed on 20/05/2019 e.g. data collection tax policy. 


\section{Figure 2: Basic principles of German Commercial Code (extract)}

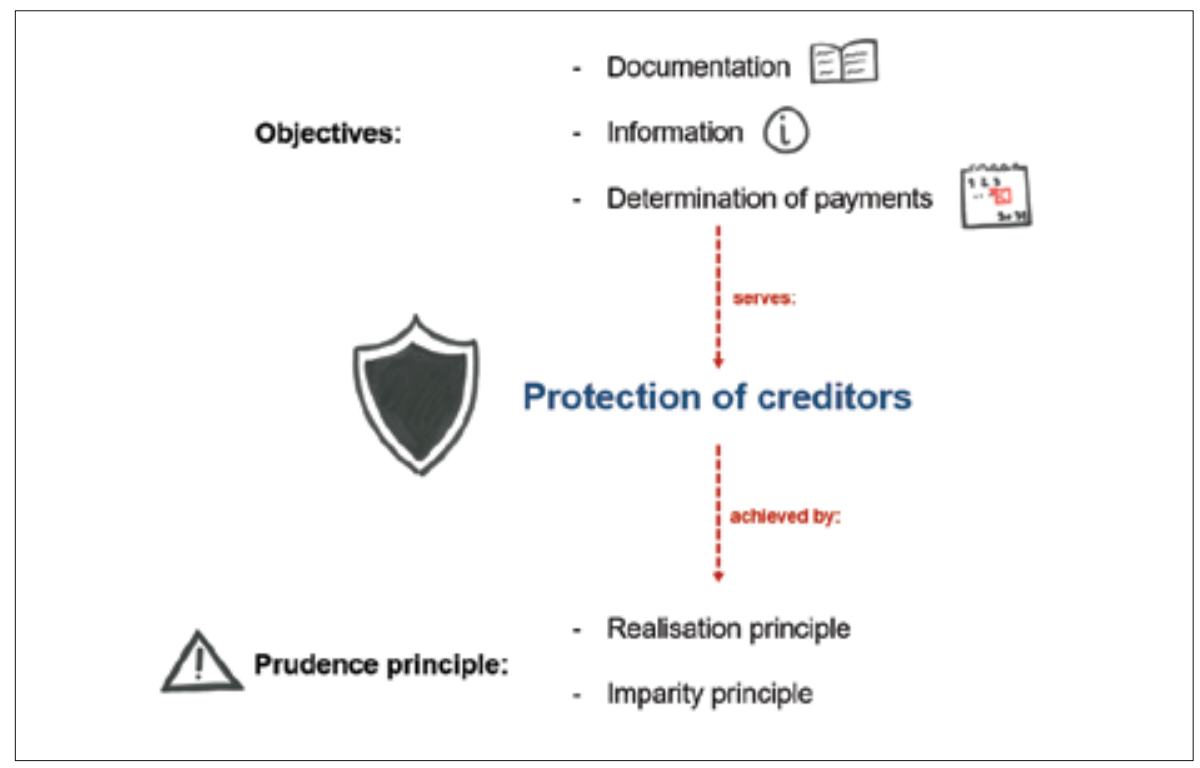

- To begin with, every merchant has to prepare a financial statement ${ }^{33}$ consisting of a balance sheet and a profit and loss account. ${ }^{34}$

- Small corporations have to give further information in the notes (unlike partnerships). ${ }^{35}$

33 See German Commercial Code [German Federal Law Gazette, Part I, p. 1102, 2018], § 242 (1). Please note, that the Directive 2013/34/EU does not involve the sole proprietor as it is known in the German Commercial Code. The Directive refers to legal forms which are characterised by a limited liability, see Directive 2013/34/EU [Official Journal of the European Union, L 182/19, 2013], Art. 1 (1) lit. a and lit. b in conjunction with Annex I and Annex II.

34 See German Commercial Code [German Federal Law Gazette, Part I, p. 1102, 2018], § 242 (3). The law has fixed formats for these components, German Commercial Code [German Federal Law Gazette, Part I, p. 1102, 2018], § 266 (2) in conjunction with Directive 2013/34/ EU [Official Journal of the European Union, L 182/19, 2013], Art. 10 et seqq. sets the structure for the balance sheet, German Commercial Code [German Federal Law Gazette, Part I, p. 1102, 2018], § 275 (2), (3) in conjunction with Directive 2013/34/EU [Official Journal of the European Union, L 182/19, 2013], Art. 13 et seqq. the structure for the profit and loss account. 35 See German Commercial Code [German Federal Law Gazette, Part I, p. 1102, 2018], § 264 (1) sentence 4 in conjunction with German Commercial Code [German Federal Law Gazette, Part I, p. 1102, 2018], § 267 (1) and Directive 2013/34/EU [Official Journal of the European Union, L 182/19, 2013], Art. 4 (1) . 
- Medium-sized and large corporations additionally have to report about their situation in a compulsory management report. ${ }^{36}$ Directive 2013/34/ EU deals with this form of report and admit in Art. 19 (3) to exempt small undertakings from the obligation to prepare a management report. This approach mirrors the idea of the Small Business $\mathrm{Act}^{37}$ to simplify the regulatory and policy environment for SMEs. This report is a separate account and not part of the financial statement as the notes. ${ }^{38}$

- Capital market-oriented non-group corporations have to carry out most duties, namely an additional equity statement and an additional segment report. ${ }^{39}$

It should be noted that Art. 4 (1) sentence 2 Directive 2013/34/EU sets the possibility of member states to include further statements/documents in the annual financial statements. This scope is currently not drawn by the German legislator.

Figure 3: Components of financial statements depending on the size of entities

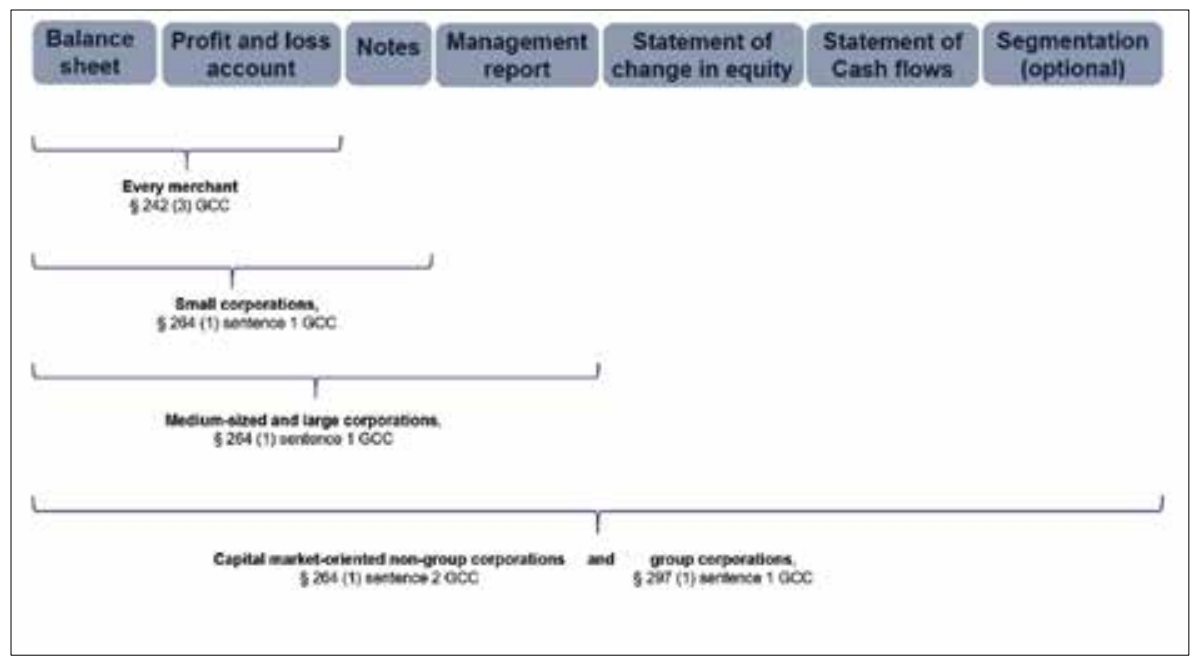

36 See German Commercial Code [German Federal Law Gazette, Part I, p. 1102, 2018], §§ 264 (1) sentence 1 in conjunction with 289. 289a, 315.

37 See for further information [https://ec.europa.eu/growth/smes/business-friendly-environment/small-business-act_en] accessed on 25/03/2019.

38 See for further information Kahle, Holger; Eichholz, Meik: Pflicht zur Aufstellung; Befreiung - Besondere Rechnungslegungsvorschriften von Kapitalgesellschaften (Abs. 1), in Hachmeister et al. (ed.): Bilanzrecht, Köln, 2018, § 264 Point 8 et seqq.

39 See German Commercial Code [German Federal Law Gazette, Part I, p. 1102, 2018], $\S 264$ (1) sentence 2. 
The strong attachment of the German Commercial Code and the EU Accounting Directive is visualized by figure 4: This illustration clarifies the parallelism and congruency of both regulations for exemplary topics.

Figure 4: Exemplary comparison of EU-law and national (German) law

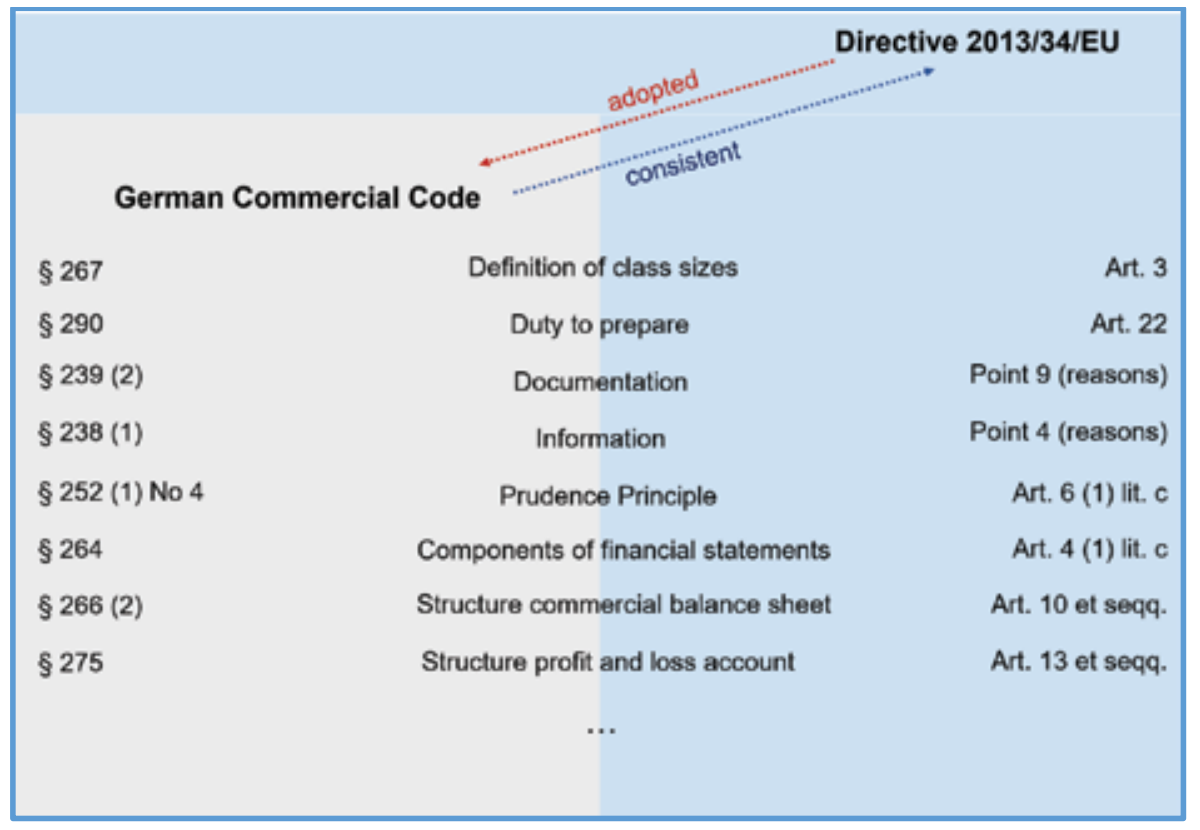

The fact that Germany is a civil law country is vital: Legislation is the most frequently used source of law - short and generally valid in a multitude of cases. ${ }^{40}$ This implies an interpretation of how the code is to be transferred into the application. This task-related to group accounting is taken care of by the DRSC (ASCG: Accounting Standards Committee of Germany). The DRSC is acknowledged by the German Commercial Code $^{41}$ and defines among other things for example how a consolidated cash flow statement ${ }^{42}$ under German law has to look. ${ }^{43}$

\footnotetext{
40 https://wp0.vanderbilt.edu/wp-content/uploads/sites/78/Picker_final_7.pdf, p. 1095 in conjunction with p. 1101.

41 See German Commercial Code [German Federal Law Gazette, Part I, p. 1102, 2018], § 342.

42 See German Commercial Code [German Federal Law Gazette, Part I, p. 1102, 2018], §§ 264 (1) sentence 2, 297 (1) sentence 1.

43 See DRS 21 (2018) German Financial Reporting Standards, [https://www.drsc.de/en/ about/] accessed on 23/01/2019.
} 


\section{GERMAN COMMERCIAL AND TAX BALANCE SHEET: INTERDEPENDENCIES}

Regarding the balance sheet, German law demands two "different" balance sheets with different objectives:

- The commercial balance sheet is used for accounting ${ }^{44}$ - especially information and documentation - whereas

- The tax balance sheet is used for calculating taxes that an enterprise has to pay. ${ }^{45}$

The tax balance sheet is based on the commercial balance sheet ${ }^{46}$, which means that commercial and tax balance sheet are alike for the beginning. ${ }^{47}$ As commercial and tax balance sheet follows the above-mentioned, different objectives: Information and documentation "versus" calculating taxes. That is why the tax law carries out different adjustments to achieve its aims and to calculate the assessment basis. ${ }^{48}$ While the legislator seeks the annual net profit reported in the commercial balance sheet prudent within its regulations (prudence principle), the legislator seeks the assessment basis for calculating the taxes less prudent. The balance sheets are therefore "linked" by the adjustments of German Tax legislation: ${ }^{49}$

44 See for further information Schmidt, Stefan; Usinger, Rainer: Jahresabschluss (allgemeine Vorschriften) - Allgemeines, insbesondere Begriff der GoB, in: Grottel et al.: Beck'scher Bilanz-Kommentar, 2018, § 243 Point 1 et seqq. in conjunction with Coenenberg (2018), p. 22 et seq.

45 See for differences between trade and tax balance sheet Schmidt, $\mathrm{x}$; Usinger, y: Titel of chapter, in: Grottel et al.: Beck'scher Bilanz-Kommentar, 2018, § 243 Point 119 et seqq. in conjunction with Coenenberg et al.: Jahresabschluss und Jahresabschlussanalyse, Stuttgart 2018, p. 22 et seq.

46 This principle is called „Maßgeblichkeitsprinzip“ (“authoritative principle”), § 5 (1) Sentence 1 German Income Tax Act.

47 See for further information Hennrichs, Joachim: Steuerrechtliche Gewinnermittlung Maßgeblichkeit der handelsrechtlichen Grundsätze ordungsmäßiger Buchführung, in: Tipke et al.: Steuerrecht, 2018, § 9 Point 44 et seqq.

48 The authoritative principle is overlapped by numerous specific tax regulations that have priority (so called "Steuervorbehalt"). Tax options (e.g. $\S \S 6 \mathrm{~b}, 7 \mathrm{~g}$ German Income Tax Act) for example can be applied independent from the commercial balance sheet, § 5 I Sentence 2 German Income Tax Act in conjunction Coenenberg et al.: Jahresabschluss und Jahresabschlussanalyse, Stuttgart 2018, p. 22 et seq.

49 See for further information Hennrichs, Joachim: Steuerrechtliche Gewinnermittlung Maßgeblichkeit der handelsrechtlichen Grundsätze ordungsmäßiger Buchführung, in: Tipke et al.: Steuerrecht, 2018, § 9 Point 41 et seqq. 


\section{Figure 5: Connection between commercial balance sheet and tax balance sheet}

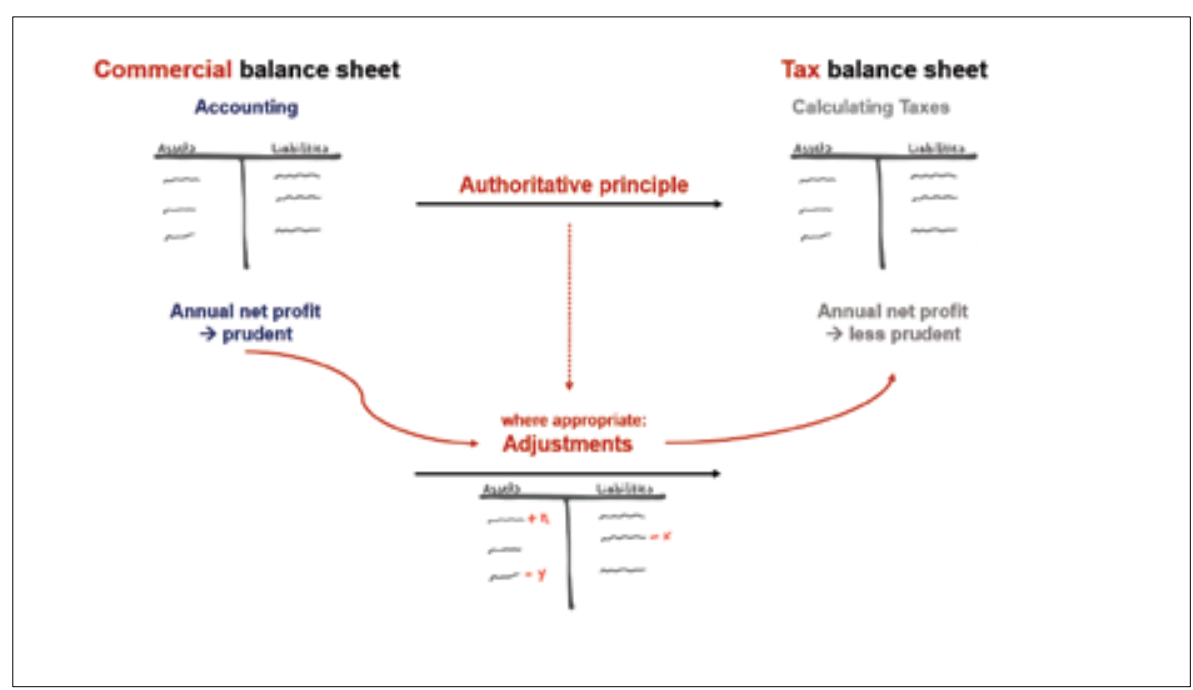

Starting point of adjustment is always the annual net profit. ${ }^{50}$ Tax wise non-deductible expenses need to be added (less prudent), which means that these expenses were deducted for the commercial balance sheet (prudence principle). ${ }^{51}$ The second step is to deduct tax-free transactions. While these transactions increased the annual net profit, the tax law wants to neutralize them for special reasons. The legislator tries to achieve non-fiscal objectives by doing this, e.g. the tax-free dividends between incorporated group entities should promote cooperation between such entities. ${ }^{52}$

$50 \quad$ See German Income Tax Act [German Federal Law Gazette, Part I, p. 357, 2019], § 5 (1). Please note that the following example (including figure 5) relates to a corporation, which is subject to the German Corporation Tax Act (that relates partially to the German Income Tax Act).

51 See for example German Corporation Tax Act [German Federal Law Gazette, Part I, p. 357, 2019], § 10 (1).

52 See German Corporation Tax Act [German Federal Law Gazette, Part I, p. 357, 2019], $\S 8 \mathrm{~b}(1)$. 
Figure 6: Calculating corporate taxes under German law

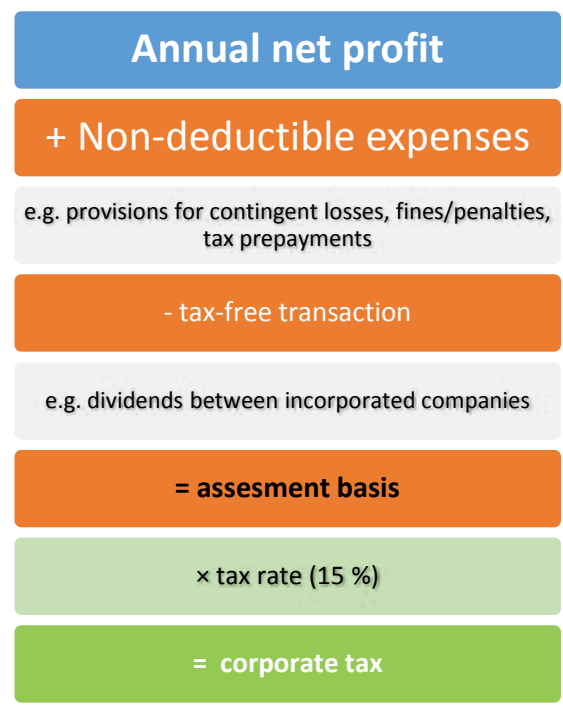

\section{Trade balance sheet}

\section{adjustments}

\section{Tax balance sheet}

\section{CROATIAN FINANCIAL REPORTING: STANDARDS AND REGULATIONS}

Croatian most important legal act that regulates the accounting area is the Accounting Act. Besides, entrepreneurs that operate in Croatia should be aware of the Rule on annual financial statements' structure and content. On contrary to many countries, the Company law is not the main legal act in charge of the regulation on accounting issues. The Croatian Companies Act regulates basic types of business forms (joint-stock companies, limited liability companies...), the entry in the commercial register, liquidation, and many other legal issues important to corporations. ${ }^{53}$ There are some matters regarding accounting and auditing that are regulated by the Croatian Companies Act. For instance, the determination of financial statements, some issues related to the structure and changes of capital, the distribution of profit, etc. It has to be pointed out that, the Company law prescribes some issues that are of importance to accountant's work, but there isn't any separate chapter dedicated to the accounting matters as it is for example in the case of the German Commercial Code, where the $3^{\text {rd }}$ book from $\$ \S 238$ onwards deals with commercial books of accounts.

53 Companies Act (National Gazette No. 111/93 - 40/19). 
The Accounting Act regulates questions on:

- the classification of entrepreneurs and groups,

- bookkeeping documents and business books,

- inventory,

- financial reporting standards,

- body in charge of the standard-setting process,

- annual financial statements,

- consolidation of annual financial statements,

- the report on payments to governments,

- audit of annual financial statements and management report,

- the content of management report,

- public disclosure of annual financial statements and management report,

- the Register of annual financial statements,

- oversight. ${ }^{54}$

The EU Accounting Directive ${ }^{55}$ is introduced in the Accounting Act and the related acts (the Rules on annual financial statements' structure and content and the Croatian Financial Reporting Standards).

\footnotetext{
54 Article 1, Accounting Act, (National Gazette No. 75/2015, 134/2015, 120/2016, 116/2018) [https://narodne-novine.nn.hr/clanci/sluzbeni/2015_07_78_1493.html] accessed on 20/05/2019. 55 See European Union: Directive 2013/34/EU, [https://eur-lex.europa.eu/legal-content/EN/ TXT/?uri=CELEX:32013L0034] accessed on 23/11/2018. For more information please see European Commission: Accounting rules - Directive 2013/34/EU, [ https://ec.europa.eu/info/law/ accounting-rules-directive-2013-34-eu_en] accessed on 23/11/2018.
} 
Figure 7: Exemplary comparison of EU-law and national (Croatian) law

Croatian Accounting Act

Art. 5

Art. 23

Art. 13, 19

Art. $7-10,12-14$

CFRS 1.3.

Art 19 .

The Rule on annud financial

statements' structure and ccrtent

The Rule on annual finandial

ststements' structure and content
Definition of class sizes

Art. 3

Duty to prepare group accounts

Art. 22

Documentation

Information

Prudence Principle

Components of financial statements

Structure commercial balance sheet

Structure profit and loss account
Point 9 (reasons)

Point 4 (reasons)

Art. 6 (1) lit. $c$

Art. 4 (1) lit. $c$

Art. 10 et seqq.

Art. 13 et seqq.

The Rule on annual financial statements' structure and content prescribes the structure and the content of balance sheet, profit and loss account, cash flow statement, statement of changes in equity and gives some requests on the content of the notes to the financial statements depending on the size of the entrepreneurs. ${ }^{56}$

According to the Accounting Act micro, small and medium entities should apply the Croatian Financial Reporting Standards (CFRS) and the rest, i.e. large entities and public-interest entities shell apply the IFRS. A subsidiary whose parent company applies the IFRS can decide to apply the IFRS for the preparation of its financial statements. ${ }^{57}$

As can be seen from the table 1, there were 118740 entrepreneurs in 2016 based on Financial Agency evidence. 99,4\% of total entrepreneurs have the obligation of preparing financial statements under CFRS and the rest are those entrepreneurs that apply IFRS. The majority of the entities are micro and small entities. However, large entities are of great importance to the Croatian economy since they employ the largest number of employees, generate the greatest

\footnotetext{
56 The rule on annual financial statements' structure and content, (National Gazette No. 95/2016).

57 Article 17. Accounting Act, (National Gazette No. 75/2015, 134/2015, 120/2016, 116/2018)

[https://narodne-novine.nn.hr/clanci/sluzbeni/2015_07_78_1493.html accessed on 20/05/2019.
} 
amount of income. Interesting is that, although the Accounting Act generally anticipates that micro, small and medium-sized entities apply CFRS, there are 251 of them which apply IFRS.

Table 1. Entrepreneurs according to the financial reporting standards

\begin{tabular}{|c|c|c|c|}
\hline $\begin{array}{c}\text { Entrepreneurs according } \\
\text { to their size }\end{array}$ & $\begin{array}{c}\text { Entrepreneurs } \\
\text { that apply IFRS }\end{array}$ & $\begin{array}{c}\text { Entrepreneurs } \\
\text { that apply CFRS }\end{array}$ & TOTAL \\
\hline Micro & 108 & 106580 & 106688 \\
\hline Small & 47 & 10205 & 10252 \\
\hline Medium & 96 & 1253 & 1349 \\
\hline Large & 451 & 0 & 451 \\
\hline
\end{tabular}

Source: Financial agency based on annual financial statements for 2016. Quoted by: OSFI Annual report for 2017, 2017. [http://www.osfi.hr/Uploads/1/2/44/350/Izvjesce_o_radu_Odbora_za_standarde_financijskog_izvjestavanja_za_2017..pdf] accessed on 20/05/2019

The Croatian Accounting act prescribes that entities apply double-entry bookkeeping principle, orderly bookkeeping principle, unchangeable entry principle and the principle of equality between the ending balances from ending balance sheet and beginning balances from beginning balance sheet. It prescribes neither prudence accounting principle nor any other accounting principle for the recognition or measurement of the financial statements items. The Accounting Act rather throws over such right on the IFRS and CFRS. Further, according to the Croatian Accounting Act, annual financial statements should present fair and true view of financial position and business performance that are based on accurate, reliable and complete business records and bookkeeping records.

The Croatian Financial Reporting Standards seek from the obligators to be in line with several general financial reporting principles: going concern, accrual principle, materiality and aggregation, consistency, comparability, prudence, set-off principle, balance sheet continuity, and item separate measurement principle. ${ }^{58}$

58 OSFI (2015) Croatian Financial Reporting Standards, [http://www.osfi.hr/Uploads/1/2/136/137/Hrvatski_standardi_financijskog_izvjestavanja.pdf accessed on 20/05/2019. 


\section{CROATIAN COMMERCIAL AND TAX BALANCE SHEET: IN- TERDEPENDENCIES}

The Croatian normative accounting framework consists of several separate tax acts (the Value Added Tax Act, the Profit Tax Act, the Income Tax Act, etc.) as well. Accountants are usually familiar with those acts. The Profit Tax Act is of great importance for accountants since financial accounting and tax accounting are separated in Croatia. Namely, entities prepare financial statements under the IFRS or the CFRS and these standards offer several alternatives which managers of the entities select as their accounting policies. On the other hand, the Profit Tax Act recognizes only those methods that are defined in the Act. For instance, one can select the weighted average cost method since the CFRS and the IFRS allow that method, but for taxation purposes, this method cannot be recognized. Namely, the Profit Tax Act allows only the FIFO method. This is why companies should differentiate the trade balance sheet from tax balance sheet. The adjustments should be done in accordance with tax regulation when calculating tax liability (figure 8).

Figure 8: Calculating corporate taxes under Croatian law

\begin{tabular}{|} 
Annual net profit \\
+ increase of profit/decrease of loss \\
$\begin{array}{c}\text { e.g. impairment losses on non-current tangible } \\
\text { and intangible assets }\end{array}$ \\
- decrease of profit/increase of loss \\
e.g. dividend income \\
$=$ tax basis \\
$\times$ tax rate (12 \% or $18 \%)$ \\
$=$ tax liability \\
- tax relief and tax stimulation \\
\hline = total corporate tax
\end{tabular}

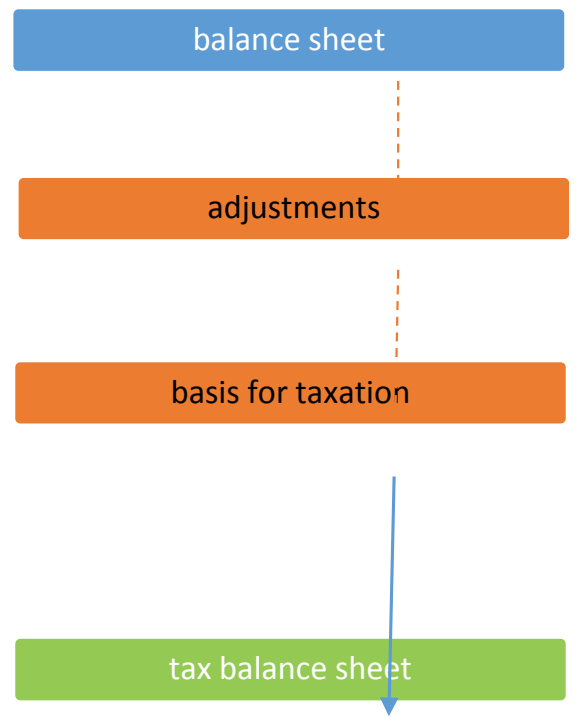

\section{CONCLUSION}

In conclusion, the German Commercial Code is the most central code in German accounting. Nevertheless, German accounting is influenced by other regulations (especially EU/IFRS) and influences for its part the taxation of 
entities: A holistic overview concerning these interdependences is substantial for economic control of an entity. Unlike Germany, the Croatian accounting framework is marked primarily through the Accounting Act and the Rule on annual financial statements' structure and content. Besides, the Companies Act is significant since it regulates some parts from the accounting field but more precisely legal parts for doing business in Croatia. Also, an entity that operates in Croatia must be familiar with several separate tax laws.

The prudence principle is immanent for German accounting; even the introduction of IFRS has not harmed its dominance. Nevertheless, the influence of European legislation as well as IFRS regulations is tremendous; being familiar with these policies links accountants of the countries concerned substantially. This fact should be seen as an opportunity to gain economic success, understand business partners and develop current policies. Croatian Financial Reporting Standards introduce several general financial reporting principles, among others, the prudence principle as well. Similar to Germany, the Republic of Croatia, as the EU Member State has implemented the EU Accounting Directive in its accounting regulation.

From the international operation perspective, the similarities and differences between the accounting systems in Croatia and Germany are interesting for scientific international accounting literature but also they are of great importance to the practitioners, especially those ones that do foreign direct investments. The globalization environment forces us to be aware of the national specifics and their influence on different fields of operation. As an important difference can be stated that non-public large German corporates are obliged to account for German Commercial Code in single and group accounting while non-public large Croatian corporates are obliged to account for IFRS. For further research and more comprehensive and deeper analysis it would be interesting to compare accounting principles for the recognition and measurement of assets and liabilities that are implemented as German and Croatian generally accepted accounting principles.

\section{LITERATURE}

1. Accounting Act, National Gazette 109/2007 https://narodne-novine.nn.hr/clanci/ sluzbeni/2007_10_109_3174.html

2. Accounting Act, National Gazette 146/2005 https://narodne-novine.nn.hr/clanci/ sluzbeni/2005_12_146_2736.html

-DOI: https://doi.org/10.1002/ckon.200590027

3. Accounting Act, National Gazette 75/2015, 134/2015, 120/2016, 116/2018 https:// narodne-novine.nn.hr/clanci/sluzbeni/2015_07_78_1493.html 
4. Accounting Act, National Gazette 90/1992, https://narodne-novine.nn.hr/clanci/ sluzbeni/1992_12_90_2331.html

5. Auditing Act, National Gazette, 127/17, https://www.zakon.hr/z/417/Zakon-o-reviziji

6. Bundesministerium der Finanzen: Datenportal, available at: https://www.bundesfinanzministerium.de/Datenportal/start.html [20.05.2019].

7. Bundesministerium der Finanzen: Datensammlung zur Steuerpolitik, 2018.

8. Coenenberg, Adolf/Haller, Axel/Schultze, Wolfgang: Jahresabschluss und Jahresabschlussanalyse, 25. Auflage, 2018.

-DOI: https://doi.org/10.34156/9783791041230

9. Companies Act (2019) National Gazette 111/93 - 40/19.

10. Companies Act 2006, available at: https://www.legislation.gov.uk/ukpga/2006/46/ contents

11. Croatia: Foreign investments, available at: https://en.portal.santandertrade.com/ establish-overseas/croatia/investing

12. Croatian Financial Reporting Standards,

13. Deutsche Telekom AG: Deutsche Telekom in Croatia, available at: https://www. telekom.com/en/company/worldwide/profile/deutsche-telekom-in-croatia-355850 [29.10.2018].

14. Deutsches Rechungslegungs Standards Committee e. V.: About the ASCG, available at: https://www.drsc.de/en/about/ [23.01.2019].

15. Deutsches Statistisches Bundesamt: Unternehmensregister-System, available at: https://www-genesis.destatis.de/genesis/online/data;sid=4716881764427D759DB 81CA028DB82E5.GO_1_3 [27.03.2019].

16. Directive 2013/34/EU of the European Parliament and of the Council of 26 June 2013, http://eur-lex.europa.eu/legal-content/EN/TXT/PDF/?uri=CELEX:32013L0034\&from $=$ EN

17. European Commission: Accounting rules - Directive 2013/34/EU, available at: https://ec.europa.eu/info/law/accounting-rules-directive-2013-34-eu_en [23.11.2018].

18. European Commission: SME Performance Review - The annual report, S. 13 et seq., available at https://ec.europa.eu/growth/smes/business-friendly-environment/performance-review_de [10.01.2019].

19. European Union: The Small Business Act for Europe, available at: https://ec.europa.eu/growth/smes/business-friendly-environment/small-business-act_en [25.03.2019].

20. Federal Ministry of Justice and Consumer Protection: Commercial Code, available at: https://www.gesetze-im-internet.de/englisch_hgb/englisch_hgb.pdf [23.11.2018]. 
21. German Federal Foreign Office: Croatia, available at: https://www.auswaertiges-amt.de/en/aussenpolitik/laenderinformationen/kroatien-node/croatia/228804 [29.10.2018].

22. Grottel, Bernd/Schmidt, Stefan/Schubert, Wolfgang/Winkeljohann, Norbert: Beck'scher Bilanz-Kommentar, 11. Auflage, 2018.

23. Hachmeister, Dirk/Kahle, Holger/Mock, Sebastian/Schüppen, Matthias: Bilanzrecht, 2018.

-DOI: https://doi.org/10.9785/9783504384234

24. Hoffmann, Wolf-Dieter/Lüdenbach, Norbert: NWB Kommentar Bilanzierung, 10. Auflage, 2019.

25. http://www.osfi.hr/Uploads/1/2/136/137/Hrvatski_standardi_financijskog_izvjestavanja.pdf

26. International Accounting Standards Board: IFRS, available at: https://www.ifrs. org/about-us/ [23.11.2018].

27. OSFI (2015) Croatian Financial Reporting Standards, available at: http://www. osfi.hr/Uploads/1/2/136/137/Hrvatski_standardi_financijskog_izvjestavanja.pdf

28. OSFI (2017) Annual report for 2017, available at: http://www.osfi.hr/Uploads/1/2/44/350/Izvjesce_o_radu_Odbora_za_standarde_financijskog_izvjestavanja_za_2017..pdf

29. Picker, Colin: International Law's Mixed Heritage: A Common/Civil Law Jurisdiction, available at: https://wp0.vanderbilt.edu/wp-content/uploads/sites/78/ Picker_final_7.pdf [15.03.2019].

30. Rittler, Thomas: Handelsgesetzbuch (HGB) - German Commercial Code, 4. Auflage, 2017.

31. Seer, Roman/Hey, Johanna/Montag, Heinrich/Englisch, Joachim/Hennrichs, Joachim: Steuerrecht, 23. Auflage, 2018.

32. Siemens AG: Our history in Croatia, available at: https://www.siemens.com/global/en/home/company/about/history/countries/croatia.html [29.10.2018].

33. The rule on annual financial statements' structure and content, National Gazette No. 95/2016. 
